\title{
Re-framing infant toddler pedagogy through a lens of professional love: exploring narratives of professional practice in early childhood settings in England
}

\author{
Jools Page \\ University of Brighton \\ School of Education \\ Checkland Building \\ Falmer \\ Brighton \\ England \\ BN1 9PH \\ Ph: +4412736432761 \\ Email: j.m.page@brighton.ac.uk
}

\begin{abstract}
There is an increased international interest in how close attachment interactions with infants and toddlers are realised and interpreted by early years professionals. It is troubling for those who work in early years settings with infants and toddlers to know how best to demonstrate healthy loving attachment behaviours as an expectation of their professional caregiving role when 'standing in for parents'. This paper reports the interview findings from a mixed methods study which examined practitioners' views on love, care and intimacy within the English early years policy context. It draws on Attachment Theory and Relational Ethics to analyse the narratives of practice drawn from eight in-depth interviews with infant toddler professionals to reveal the extent of their challenge as well as their beliefs about attachment and professional love. The responses highlighted the level of concern about the place of love and intimacy in non-familial pedagogical relationships with young children, against the backdrop of child protection and safeguarding following the global concern about infant abuse. The study suggests that there is a need to embrace an infant toddler pedagogy to include the lens and the language of attachment and professional love and to provide early years professionals with training and guidance on how to safely interpret these theories into their everyday practice.
\end{abstract}

Keywords: Attachment, Care, Infants, Intimacy, Love, Toddlers

\section{Author Bio:}

Jools Page is a Senior Lecturer in Early Years Care and Education at the University of Brighton, England. Jools research focus is on attachment based relationships between adults and children under three years in group day care provision. She maintains that it is from her humble beginnings working in practice based roles with young children and their families that she first gained her unique insight into the importance of fostering careful, respectful, reciprocal and genuine relationships between infants, toddlers and their key adults. She is committed to research and practice which places the rights of infants and toddlers at the 
centre. It is this view of children which inspired her academic research into attachment, intimacy, care and love between professional caregivers and young children and, which led her to coin the phrase Professional Love. Jools disseminates her research on Professional Love through a wide variety of publications. She is a visiting scholar at the University of Huddersfield, England where her work on Professional Love has inspired colleagues to engage with her ideas and to interrogate the boundaries of love and professionalism within the context of childhood studies and youth.

\section{Funding}

The Professional Love in Early Years Settings (PLEYS) project was generously funded by The University of Sheffield, UK Innovation, Impact and Knowledge Exchange (IIKE) who (code: X/142544) in collaboration with Fennies Nurseries

\section{Acknowledgements}

The author wishes to thank The University of Sheffield, UK in collaboration with Fennies Nurseries for their generous funding; all of the participants; and the whole Professional Love in Early Years Settings project team for their valuable contributions to the study 


\section{Introduction}

Building effective and meaningful pedagogical relationships with children and families is at the heart of all early years practice. Indeed, in the absence of their parents, young children who spend time away from their own families attending early years settings are reliant on their adult caregivers to provide a physically and emotionally secure environment for them to be able to develop and learn. Yet the sexual abuse of children by female nursery workers in Plymouth, England (Plymouth Safeguarding Children Board, 2010) and the increased news coverage of abusive clergy (Barnett, 2010) and well-known household names from the entertainment industry (Operation Yewtree, 2011) - amongst many such reported cases - has led to an atmosphere of unease. This caution has led to increased suspicion and even fear amongst early years professionals in England about how to interpret policies and procedures in relation to appropriately enacting loving, intimate and caring relations when working professionally with young children.

This paper begins with a discussion of the current early years policy context in England. It then moves on to discuss the place of Attachment Theory and Relational Ethics which provided the theoretical framework for a study that investigated the views of early years professionals in England on love, care and intimacy (Page, 2015). It is the detailed reflections captured from the individual interview stage of the study which are emphasised in this paper, to reveal how infant toddler professionals realise their attachments to infants and toddlers within their professional caregiving role and to highlight the challenges and dilemmas which this role poses for them. In the final section of the paper, the implications of the research findings point to a serious need to reframe infant toddler pedagogy to include training and guidance through a lens of professional love.

\section{The English Early Years Policy Context}

Historically, infants and toddlers have not been included within English early years policy frameworks. Traditionally, adults who worked in paid roles with infants and toddlers under the age of three were considered to be carers and those who worked with children aged three years and above were seen as educationalists (Page, 2013). The first shift in policy terms came about with the launch of the Birth to Three Matters (BT3M) guidance document (DfES/Sure Start 2002) which was a major initiative for professionals working with the youngest children. It was accompanied by an extensive literature review (David, Goouch, Powell \& Abbott, 2003) 
which scoped a plethora of research about the competencies as well as the fragilities of young children under the age of three. At the heart of the BT3M framework was the emphasis on the security of adult-child relationships and the importance of fostering primary caregiving (which in England is termed the key person approach) (Elfer, Goldschmied and Selleck, 2011). The launch of the Early Years Foundation Stage (EYFS) single quality policy framework for children aged from birth to five years (Department for Children, Schools \& Families, 2008) retained the key messages from the BT3M guidance and the role of the key person became enshrined in law. This was a historically, educationally and ultimately morally important moment: the first time that infants and toddlers were included in a formal educational policy which catered for both care and education. Yet, within the context of childcare expansion rhetoric (Department for Education \& Skills, 2004), concern continued to be raised about professional qualifications (Mathers, Eisenstadt, Sylva, Soukakou, \& Ereky-Stevens, 2014) and the ability of the workforce to provide suitable educative experiences for children came under severe scrutiny (Her Majesty’s Treasury, 2009).

It is not my intention in this paper to debate the qualifications agenda with regard to the early years workforce, except to point out that in the context of raising quality, caring is frequently diluted in favour of education (Goouch \& Powell, 2016; Organisation for Economic Cooperation \& Development, 2017). Thus, the divide between education and care continues to rumble on in England and elsewhere in Europe with views of education continuing to be perceived as hierarchically superior to caring (Van Laere, Peeters \& Vandenbroeck, 2012). Not only does this view demonstrate the enduring hegemony of academic competences and a complete lack of understanding of the vital nature and role of caring relations, but it also simultaneously undermines the role of those who spend their time professionally in the company of infants and toddlers. What is most important for the argument in this paper, however, is the inherent challenge to attachment based relationships between paid early years professionals (known variously as practitioners, caregivers, educators, teachers and pedagogues) and young children.

At the core of the EYFS are four overarching principles including the principle that 'children learn to be strong and independent through positive relationships' (Department for Education, 2014, p.6). Importantly there is a mandate for children to be allocated a key person and that, 'The key person must help ensure that every child's learning and care is tailored to meet their individual needs' (p.10). Yet, how early years settings realise the role of the key person is challenging for professionals because it is interpreted at individual setting level and, as such is 
subject to criticism in relation to meeting children's individual needs (Page \& Elfer, 2013). Crucially, the EYFS includes requirements which early years providers need to adhere to in order to keep young children safe. Under the heading, 'Child Protection', for example, it states that:

Providers must train all staff to understand their safeguarding policy and procedures, and ensure that all staff have up to date knowledge of safeguarding issues. Training made available by the provider must enable staff to identify signs of possible abuse and neglect at the earliest opportunity, and to respond in a timely and appropriate way. These may include: inappropriate behaviour displayed by other members of staff, or any other person working with the children. For example: inappropriate sexual comments; excessive one-to-one attention beyond the requirements of their usual role and responsibilities; or inappropriate sharing of images.

(Department for Eduation,2014, para 3.6, p.17 my emphasis)

The challenge, though, for early years professionals - particularly those who work with infants and toddlers - is to decide exactly what behaviour constitutes 'excessive one to one attention beyond the requirements of their usual role and responsibilities' (p.17) especially within the context of tailoring learning and care to meet children's individual needs (see also Page, 2014). The love, care and intimate affection, essential to infants' and toddlers' security and dispositions to learn, has been overshadowed by an unease surrounding the possibility of false accusations of child abuse which has begun to infiltrate the early years workforce. This unease - and, anecdotally, actual fear - has engendered a widespread 'moral panic' (Piper \& Smith, 2003; Andrzejewski \& Davis, 2008; Owen \& Gillentine, 2011) which has its origins in the recent spate of child abuse convictions, particularly the case of George and Allen who were convicted of abusing babies in a nursery in South West England (reported extensively in the media (BBC News, 2010)). Barnett (2010) pointed out the shortfalls of the nursery and in particular how "staff became increasingly uncomfortable and worried about George's behaviour, but felt they had nowhere to go with these feelings" (n.p). Undoubtedly, these shocking crimes make sobering reading. Worryingly, however, available guidance for early years professionals on how to appropriately meet the attachment needs of infants and young children is completely lacking. It is reasonable to assume, therefore, that young children are at risk of being denied the opportunity to become closely attached to their key person and are in danger of being kept at 'arm's length' by well-meaning but anxious caregivers who are fearful of being accused of wrongdoing; I see this as no less than a widespread but largely unacknowledged crisis of care. 


\section{Attachment and Caring Relations: theoretically framing infant toddler relationships}

Based on a series of in-depth observations of the reactions of young children in hospital who when separated from their parents displayed a range of emotions namely, fear, anger, sadness and despair, John Bowlby (1969) claimed the infant mother relationship was different to other adult child relations, arguing that a child would suffer harm if separated from her. Influenced by the results of Ainsworth \& Bell's (1970) 'strange situation test’ Bowlby (1973) regarded a child's 'internal working model' - that is to say their ability to predict the reliability of a caregiver's availability - is based on the infant's previous experience of being cared for. Thus, he claimed the 'attachment bond' formed in the first two years of life is crucial to all other attachments. Since it was first generated Attachment Theory has had far reaching consequences with new debates and directions being applied by contemporary scholars from across a variety of disciplines (Cassidy \& Shaver, 2008). As Rutter (2008) argues because Bowlby’s initial observations stemmed from hours of watching children in hospital who had been separated from their parents in an institutional context, this view has provided a useful perspective on how to inform and improve childcare practices. It is fair to say that Attachment Theory (Bowlby, 1969) has long been used as both a 'stick and carrot' in relation to infant toddler day care, with some protagonists using Bowlby's theories to ‘guilt trip’ parents (usually mothers) for going to work, claiming that the child will be irreparably damaged by this separation from the mother and most especially in the first year of life. Others, of course, have argued that parents have a right to work as well as to family life, claiming that in formal early years settings where the baby is firmly attached to one or two special adults then he or she will not suffer irrevocable harm (Rutter, 1995, Cassidy, 2008).

Although it seems unlikely that a consensus view will be reached on this, it is factually and firmly evident that parents do work and babies are attending early years settings (Hillman, \& Williams, 2015). Thus, when infants and toddlers spend much of their time away from their own homes and families, the quality of these non-familial experiences of care and education, moreover, the intensity of the adult-child relationship, has increasingly become a hot topic for debate not just in England (Anderson, Day and Speight, 2017) but as part of a wider global discourse (Degotardi \& Pearson 2014; Redder \& White, 2017). Yet, the point about the proximity of the child's attachment figure, which in his later work Bowlby (1982) conceded did not necessarily need to be the natural mother, still makes sense in the context of childcare and education in the twenty first century and is in contention with the notion put forward by 
Trevarthen (2004) and Dahlberg, Moss \& Pence (2007) that an infant's attachment to a close adult inhibits play and exploration with peers (Bowlby, 1969/1982, p.30 in Cassidy, 2008, p.9).

In spite - or arguably because - of their controversy, there persists an important and vocal support for the merit of Bowlby’s ideas. Gerhardt (2015) claims that studies by Daniel Stern and Allan Schore were heavily influenced by theories of attachment and, continue to provide a highly relevant context in which to scrutinise the nature and complexity of adult-child relationships in and out of the home as noted by other contemporary writers (Chazan-Cohen, Zaslow, Raikes, Elicker, Paulsell, Dean, \& Kriener-Althen). In agreement with Bowlby, Gerhardt (2015) points out that for infants, the idea that there is some sort of representation, (i.e the internal working model, Bowlby, 1973) to call upon about how an adult will respond to an infant's bid for attention is imperative to how relationships are formed throughout life. I suggest therefore, it is absolutely essential for early years professionals who work with the youngest children in society to understand that when infants seek close proximity to their key person (Department for Education, 2014) this way of being is a normal and healthy aspect of an infant's desire for comfort and affection. Thus, in line with Bowlby and Gerhardt's thinking if an adult ignores or dismisses an infant's demand for attention, then for the child this behaviour represents rejection. I turn now to Noddings (2003) notion of the ethic of care to frame my theoretical position on love within the context of professional attachment relationships between adults and young children in early years settings.

The Ethic of Care theory proposed by Noddings (1984) is situated within a feminine approach to ethics and moral education and takes the view that caring relations are not a set of behaviours which come with a prescribed way of behaving, but rather that ethical caring is about enacting with thought as well as with feeling. It is this notion of feelings which feminist critics (Hoagland, 1990) claim position women as somehow inferior to men, particularly when drawing upon a model of women in their mothering role (p.109). Noddings (2003) refutes this assertion, maintaining that her theory of caring applies equally to both men and women. It is her contention that for one to act with ethical care is to be compelled to care but that there is a choice involved, which she insists is different from innate caring which is based largely on intuition and fits more readily with familial care. The idea that caring involves being in tune with the one in need of caring, according to Noddings involves the carer 'being in reception' with the cared-for, which she calls 'motivational displacement' (2003, p.30). It is the adult's ability to de-centre, (i.e to forego his or her own opinion and to imagine being as if in the position of the one needing care-ing) which I believe fits entirely into the context of early years 
practice and in particular when working with infants and toddlers (see Page, 2011 for further explanation). Noddings' theory underpins the development of my notion of Professional Love; that when the adult caregiver is able to de-centre and form an authentic, enduring and close relational attachment to a young child, with the 'permission' from the parent, then this model of caring can be construed as a form of professionally loving practice. The challenge however, for early years professionals is to know how to provide an appropriate love to infants and toddlers without fear of reprisal. My claim is that when the key person possesses both the intellectual capacity and the emotional resilience to understand the complexity of human relations in line with the thinking developed by Ainsworth \& Bowlby (1991) on Attachment Theory and Noddings' (2003) Ethic of Care then s/he is more likely to be better equipped to offer a suitable professional attachment relationship with infants and toddlers. It is this relationship which I have termed Professional Love (Page, 2011). Indeed, as the EYFS points out, every child is 'unique' (Department for Education, 2014, p.6) and as Bowlby (1988) argues, young children thrive when they feel safe, secure and indeed loved. It stands to reason therefore, that caregivers should be provided with advice and guidance on the infant's 'internal working model' (Bowlby, 1973), and furnished with the knowledge that security of attachment for young children will take varying forms and will take longer to attain for some children than others. Security of attachment is crucially important for young children's social and emotional development of that, I contend, there should be no doubt.

\section{The study: capturing views of love, intimacy \& care within the English policy context}

In 2015 I developed and led an ongoing mixed method study, Professional Love in Early Years Settings (PLEYS; this is a collaborative research project set up specifically to examine how those who work in early years settings with children aged birth to five years in England, can safely express the affectionate and caring behaviours which their role demands of them (Department for Education, 2014); and which drew for its data on an online anonymous questionnaire, focus groups and individual in-depth interviews. I have reported elsewhere on the results of the online survey which yielded over seven hundred questionnaire responses and included home based as well as group care practitioners (Page, 2016). Two hundred respondents to the survey stage of the study volunteered to participate in a deeper level of enquiry, but the interview stage had been designed to include only a small sample of in-depth interviews. After careful consideration, interview participants were selected on the basis of location, ease of travel and mutual availability of both the participant and researcher. As a result, five interviews were audio recorded, transcribed verbatim and returned to the 
participants for verification. A further three interviews took place by email because we were keen to incorporate participant views in parts of the country where we were unable to easily travel, and yet, fitted our criterion of professionals who worked in a practice based role with children under three years. Identifying features were removed from the data and agreement was sought from all participants for use prior to analysis. Table 1.1 below, profiles the eight interviewees.

Insert Table 1:1 about here

\section{Capturing the minutiae: the narratives of infant toddler practice}

The interviews were systematically analysed using a thematic approach which comprised moving back and forth through the transcripts using line by line colour coding to allow the emergence of key themes (Creswell, 2013). It became acutely apparent that issues regarding safeguarding and child protection dominated the data as well as the anticipated theme of love. Data interpretation suggested that the level of concern raised by the participants increasingly pointed to the tension between policy and practice, as participants admitted to feeling confused about how to realise appropriate loving behaviours. The interviews captured the participants' struggle to best meet the needs of infants and toddlers within a climate which had become progressively suspicious of the motives of adults who form close attachment relationships with young children as discussed earlier in this paper. Unsurprisingly there was theme overlap, yet what became highly apparent were the inconsistences in participants' reporting of their everyday practice in relation to their enactment of professional pedagogical infant and toddler relationships. The lack of knowledge, understanding and guidance or even the opportunity to discuss the minutiae of their human interactions with children, with parents, indeed with one another, was palpable and is in contrast to the recommendations of the Plymouth Serious Case Review board (2010) (following the convictions of child abuse by childcare workers). The following vignettes highlight the confusion the study participants reported about the appropriateness surrounding the intensity of their professional attachments to infants and toddlers in their care. The first two extracts focus on the challenges and dilemmas and report on the steps participants took to 'protect' themselves or their colleagues from accusations of wrong doing which, as they indicated, would be disastrous for their career.

So, we did have a little girl that at her previous nursery, there had been an allegation against a member of staff - inappropriate touching, so the staff [here] were 
particularly conscious of changing that child, so would always say [to one another], 'Would you mind just being near?' But, on the whole, where it is sort of within the main nursery...it's got a screen, so it's sort of discreet; it's respecting the children's privacy, but also people are visible, as well. So, it is something that we're aware of and does impact on our practice probably - you know. If we were entirely homely, you'd have a separate total bathroom, wouldn't you? And you'd go and get changed there, on your own, but obviously we don't set up like that...The staff are aware of how anything they do might be perceived, and they're conscious that they wouldn't want to ... do anything inappropriate...If a child's soiled themselves...it's very hard not to be very intimate...In the past, we did have a little shower...but we were saying, 'Well, I can't imagine, really, a scenario that I'd give a child a shower... So, on the whole we use lots of wipes...but you would [use a shower] at home, wouldn't you? But it feels like a boundary...I mean, whenever there's been a story in the news, you know, an allegation at a nursery, the staff or an accident...some parents might be quite anxious...some parents really want to know when we've done our safeguarding training...

(Jane)

If you know you're safe on yourself against allegations then it would be very difficult for someone to make an allegation against you. If I was going to change a child I'd make sure that other staff know I was going to do it, you know, that the child know, they're aware, make sure I sign all the correct forms for example... I'm in view of others at the same time so...others could see that I wasn't doing anything untoward...Yeah [we are] protecting, against allegations...that in turn should protect the children because the procedures are in place to make sure the children are protected and the staff are protected as well... Things like nappy cream, that's always something I found was really difficult, ...I don't know why but I think it becomes because it's more of a you have [to] place it directly, so personally... I always feel a bit uncomfortable doing it... kind of, very intimate thing I think.

(Matthew)

Jane and Matthew both commented on the intimate nature of nappy changing. It was particularly striking that Jane was under the perception that it was inappropriate to shower a child who was heavily soiled and that using lots of wet wipes seemed to somehow be more acceptable. Matthew's point about applying nappy cream emphasised the everyday dilemmas early years professionals face when carrying out intimate care routines. It was clear during the interview that he wanted to act with integrity and respect toward the child and that he consciously tried to put aside his own uncomfortableness. This view fits with Piper \& Smith's (2003) contention that this notion of 'moral panic' can prevent professionals from working in ways that are normal and natural and resonate with the findings of the study by Andrzejewski \& Davis (2008) about how teachers made decisions regarding touching pupils and the discussion by Owen \& Gillentine, (2011) about the particular fear for male caregivers about 
being falsely accused of inappropriate touch. Participants commented on their levels of confidence with regard to how they made decisions about attachment interactions and feelings of love.

We communicate the need for children to be "loved" very clearly with parents.... Children need to be loved - boys and girls by men and women. We cannot allow the media to disrupt this basic human right. It is imperative that we identify and prevent inappropriate behaviours but this cannot be at the expense of meeting children's emotional needs.

(Donald)

I think...you've got to know your children... especially the babies. You've got to really know them and know when something's not right with them. But I think practitioners need more guidance on what that looks like and how to build it up. Because, as I said, again, there's lots on attachment and why it's good for a child/how it develops them, but there's nothing for a practitioner to say, 'Well, actually, this is what it looks like in practice.' For me... I love the children that I work with, and I want a common goal to see them develop and thrive as much as they can, and it's being that secure base for them to kind of explore and be confident to explore, but it's also being that person that they know they can come to; they can have a cuddle with. Some children just have one of those days, like everybody else does, where they just want to be with you and, for me, it's being that person but being confident in that, as well, because if you've got a practitioner who isn't confident in it, but then is trying to express that, you can maybe give confused signals to the children.

(Valerie)

Because I think the younger children, in particular, need a sort of bond with people who they are looked after by a lot that I would say would be described as love, whereas I think to use that word on its own... it needs qualifying because it's not the same sort of love that you might expect them to have with a parent or relative or whatever. So, I think it's also good to qualify it, to make it clear that you're sort of making a distinction.

These participants recognise that babies in particular need to know they are loved but Kim considered it important to qualify love. Regardless of media and public alarms, Donald had no qualms about saying he loves the children in his care, emphasising the lengths he and his team go to ensure children are protected but also know they are loved, Valerie and Kim draw on their own mothering roles to highlight their points. Kim said she does love the children but had concerns which related to her own feelings of anxiety about how her daughter might come to love her caregiver more than her - which is consistent with the views of participant mothers in reported previous studies related to childcare and love (Nelson, 1990 cited in Vincent and Ball 2006, Page, 2011; 2013). The important point here is that this dilemma influenced Kim’s lack 
of confidence in her professional role and prompted her to find an alternative term to refer to feelings of love which she believes appropriately fit with the affection and regard she has for the children she is responsible for in her paid childcare role yet, she was uncomfortable using the actual term 'love'.

It was clearly apparent from the data analysis that even though all of the participants demonstrated their knowledge about the need for young children to be loved and to be attached to close adults (Bowlby,1982), there remained a level of confusion for them about how to appropriately show affection and love in their professional role. This finding echoes the inconsistencies reported on by Andrzejewski and Davis (2008) regarding how teachers in their study made choices about touch in a risk averse climate. Furthermore, although the participants had knowledge of Attachment Theory, they were not always confident enough to apply this knowledge to their practice. Kim and Valerie demonstrated the capacity to think about parental views but this stemmed from their own frame of reference as mothers, rather than from the ethic of care perspective proposed by Noddings' (2003) or the professional love framework which I am suggesting here.

When it came to asking participants to describe the kind of policy guidance they thought would be useful, they suggested a range of ideas which overwhelmingly pointed to the need for practical training to support them to feel more confident in their decision making associated to relational pedagogy with infants, toddlers and their families. Cara and Valerie suggested that "guidance should set out the boundaries of appropriate attachments" to "build practitioner confidence" and Donald claimed there is a need to "agree what constitutes appropriate and inappropriate behaviours in terms of adult. interactions with children including use of language, development of relationships, touch, response to children's behaviour and adult initiated interactions". Matthew called for guidance to "separate the myths from the facts". When putting a child on his lap or hugging a child he explained how colleagues had expressed their concern with comments such as: “oh you can't do that!' and how he had thought: "Who says I can't do that, this is my nursery, no-one's told me I can't do it' who says that? no-one's actually said ... 'do you know what, there's a law there, you can't do that', if there is then obviously you have to abide by it. But things like that which are very difficult to understand ...where these things come from...”

Overwhelmingly, the participants were able to articulate their critical understanding of love and affection for infants and toddlers in non-familial settings. Yet, in keeping with the views 
of Owen \& Gillentine (2011) their confidence and professional practice was dominated by a climate in which they are fearful of being falsely accused of child abuse. As this study has shown this leaves many unanswered questions about how policy is interpreted and practice enacted when guidance about appropriate love and intimacy in early years is lacking.

\section{So... what are the implications of these findings?}

This paper has reported the experience of eight participants in a study in England designed to examine early years professionals' views about love, care and intimacy in early years settings. Interview data revealed how participants struggled to realise practices which meet the individual needs of young children while being careful not to leave themselves open to false accusations of child abuse. As this study demonstrates, there remain many unresolved issues, not least how early years professionals can be more confident in their decision making about love, care and intimacy, whether love can be taught and, if so, can or should love ever be rendered in a checklist, its virtues criterially observable? My contention is that if early years professionals do not know how to translate theory and policy about love and intimacy into their everyday practice, it not only renders them unable to confidently respond to accusations of wrongdoing, it neglects the emotional needs of infants and toddlers which I contend could ultimately be catastrophic for them.

The findings of the study point to the urgent need for practical advice and guidance for early years professionals at all qualification levels who are longing for training which explores notions of love, intimacy and care:

- to separate the 'myths' from the 'facts'

- to agree what constitutes appropriate and inappropriate behaviours in terms of adult interactions with children and information

- to reassure early professionals about how to make healthy relationships with children which are natural and normal

The fact that views of love are gaining traction within contemporary early years practice beyond English shores, for example, in New Zealand (Dalli, 2015; White, 2016), Hungary, (Campbell-Barr, Georgeson \& Nagy Varga, 2015), United States of America ( Recchia, \& Shin, 2010) and Australia (Degotardi \& Pearson, 2014) suggests to me that the term 'Professional Love' (Page, 2011) provides a useful lens and language in which to critically debate and reframe a global discourse on love, intimacy and care for infants and toddlers 
within the context of a risk adverse climate about affectionate caregiving in early years practice.

\section{References}

Ainsworth, M. D. S., \& Bowlby, J. (1991), An ethological approach to personality development. American Psychologist, 46, 331-341

Ainsworth, M. D. S., \& Bell, S. M. (1970). Attachment, exploration, and separation: Illustrated by the behavior of one-year-olds in a strange situation. Child Development, 41, 49-67.

Anderson, M. Day, F \& Speight. S. (2017). Study of early education and development (SEED) London: DfE.

Andrzejewski, C., \& Davis, H. (2008). Human contact in the classroom: Exploring how teachers talk about and negotiate touching students. Teaching and Teacher Education. 24. 779794

Barnett, A. (2010) Catholic abuse in England and Wales revealed. Channel 4 News, September 15 2010: Accessed August 17, 2017 http://www.channel4.com/news/articles/world/catholic\%2babuse\%2bin\%2bengland\%2 band\%2bwales\%2brevealed/3767082.html\#link1

BBC News (2010) Little Ted's was 'ideal' place for Vanessa George abuse. BBC News November 4 2010. Accessed on August 172017 http://www.bbc.co.uk/news/uk-englanddevon-11682161

Bowlby, J. (1969). Attachment and Loss: Vol. 1. Attachment. New York: Basic Books. Bowlby, J. (1973). Attachment and loss: Vol. 2. Separation New York: Basic Books. Bowlby, J. (1982) Attachment and loss: Vol. 1. Attachment (2nd edition) New York: Basic Books

Bowlby, J. (1988). A Secure Base. London: Routledge.

Campbell-Barr, V. Georgeson, J. \& Nagy Varga, A. (2015). Developing professional early childhood educators in England and Hungary: Where has all the love gone?, European Education, 47(4): 311-330. 
Cassidy, J. (2008). The Nature of the Child's Ties. In J. Cassidy and P. Shaver, Cassidy (Eds) Handbook of Attachment: Theory, Research and Clinical Application (2 ${ }^{\text {nd }}$ Edn.). (pp. 3-22). London: The Guildford Press.

Cassidy, J. \& Shaver, P. (2008) Handbook of Attachment: Theory, Research and Clinical Application (2 ${ }^{\text {nd }}$ Edn.). (pp. x-xvi). London: The Guildford Press.

Chazan-Cohen, R., Zaslow, M., Raikes, H. H., Elicker, J., Paulsell, D., Dean, A., \& KrienerAlthen, K. (2017). Working toward a definition of infant/toddler curricula: Intentionally furthering the development of individual children within responsive relationships. Brief prepared for the Office of Planning, Research and Evaluation, Administration for Children and Families; or the U.S., Department of Health and Human Services.

Creswell, J. (2013). Qualitative inquiry \& research design: Choosing five approaches $\left(3^{\text {rd }}\right.$ Edn). London. Sage.

Dahlberg, G., P. Moss, and A. Pence. (2007). Beyond Quality in Early Childhood Education and Care: Languages of Evaluation. 2nd ed. London: Falmer Press

Department for Children Schools and Families (2008) The early years foundation stage: setting the standards for learning, development and care for children from birth to five, London: DCSF

Department for Education and Skills (2002) Birth to three matters: a framework to support children in their earliest years London: DfES/ Sure Start

Department for Education and Skills (2004) A choice for parents, the best start for children: $a$ ten-year strategy for childcare, London: HMSO

Department for Education. (2014). Statutory Framework for the Early Years Foundation Stage: Setting the standards for learning, development and care for children from birth to five. London, UK: Department for Education

Dalli, C. (2015 re-printed). Re-visioning love and care in early childhood. Constructing the future of our profession. The First Years Nga Huarahi Arataki. 17 ( 2), 19-25.

David, T., Goouch, K., Powell, S. \& Abbott, L. (2003) Birth to Three Matters: A Review of the Literature. London: DfES 
Degotardi, S. \& Pearson, E. (2014) The relationships worlds of infants and toddlers: multiple perspectives from theory and practice. Berkshire, Open University Press.

Gerhardt, S. (2015) Why Love Matters; how affection shapes a baby's brain. (2 ${ }^{\text {nd }}$ Edn). East Sussex, UK. Routledge.

Goouch, K. \& Powell, S. (2016). Babyworkers, care in practice. In E. J White \& C.Dalli. (Eds). Under three year olds in policy \& practice. Springer. Gateway East, Singapore (pp143-157)

Her Majesty’s Treasury (2009) Next steps for early learning and childcare building on the 10Year Strategy, Nottingham: DCSF Publications

Hillman, J. \& Williams, T. (2015). Early years education and childcare: Lessons from evidence and future priorities. London: Nuffield Foundation

Hoagland, S. (1990). Some Concerns about Nel Noddings' "Caring". Hypatia, 5(1), 109-114.

Nelson, M. (1990) Negotiated care: The experience of family day care providers, Philadelphia Temple, University Press. In: Vincent C and Ball S (2006) Childcare Choice and class Practices: Middle-class Parents and Their Children. Abingdon: Routledge. (pp.111-130)

Noddings, N. (1984) Caring: A Feminine Approach to Ethics and Moral Education, Berkeley, CA: University of California Press.

Noddings, N. (2003) Caring: A Feminine Approach to Ethics and Moral Education, (2nd Edn). Berkeley, CA: University of California Press.

Operation Yewtree with the NSPCC. (2011). Operation Yewtree is a police investigation into sexual abuse allegations, predominantly abuse of children, against the late Jimmy Savile (who died in 2011) and others. Accessed August 17 2017: http://www.operationyewtree.com/home Organisation for Economic Cooperation and Development, (2017) Starting Strong V Transitions from Early Childhood Education and Care to Primary Education. Paris: OECD.

Page, J. (2011). Do mothers want professional carers to love their babies? Journal of Early Childhood Research. 9, (3) 310-323

Page, J. (2013). Will the 'good' [working] mother please stand up?: Professional and maternal concerns about education, care and love. Gender \& Education Journal, 25 (5) 548-563

Page, J. (2014). Developing "professional love" in early childhood settings, In L Harrison and J Sumsion (Eds) (2014). Lived Spaces of Infant-Toddler Education and Care - Exploring 
Diverse Perspectives on Theory, Research, Practice and Policy. (pp.119-130). International Perspectives on Early Childhood Education and Development Series. Springer Publishing Dordrecht Heidelberg New York London

Page, J. (2015). Professional Love in Early Childhood Education and Care: https://pleysproject.wordpress.com/ Accessed 22 August 2017

Page, J. (2016). Educators' perspectives on attachment and professional love in early years settings in England. In E. J White and C. Dalli (Eds) Under three year-olds in policy and practic. Policy and pedagogy with under-three-year-olds: Cross-disciplinary insights and innovations for educational research with very young children Series. Springer. Gateway East, Singapore. ( pp131-142)

Page, J., \& Elfer, P. (2013). The emotional complexity of attachment interactions in nursery, European Early Childhood Education Research Journal 21 (4) 553-567

Piper, H. \& Smith. H. (2003). 'Touch' in educational and child care settings: dilemmas and responses. British Educational Research Journal 29(6) 879-894

Plymouth Safeguarding Children Board, (2010) Serious Case Review Overview Report Executive Summary in respect of Nursery Z. Plymouth. England. Plymouth Safeguarding Children Board

Rutter, M. (1995), Clinical Implications of Attachment Concepts: Retrospect and Prospect *. Journal of Child Psychology and Psychiatry, 36: 549-571. doi:10.1111/j.14697610.1995.tb02314.x

Rutter, M. (2008). Implications of Attachment Theory for Childcare Policies. In: Cassidy J and Shaver PR (eds) (2008) Handbook of Attachment: Theory, Research and Clinical Application 2nd edn. London: The Guildford Press, pp. 958-974

Mathers, S., Eisenstadt, N., Sylva, K., Soukakou, E., \& Ereky-Stevens, K. (2014) Sound Foundations, A Review of the Research Evidence on Quality of Early Childhood Education and Care for Children Under Three, Implications for Policy and Practice, Improving social mobility through education, The Sutton Trust, University of Oxford,

Owen, P. \& Gillentine, J. (2011) Please touch the children: appropriate touch in the primary classroom, Early Child Development and Care, 181:6, 857-868, 
UK Government (2016) Qualified teacher status (QTS): qualify to teach in England. Available at: https://www.gov.uk/guidance/qualified-teacher-status-qts\#history

UK Government (2017a) Check early years qualifications. Available at: https://www.gov.uk/guidance/early-years-qualifications-finder

UK Government (2017b) Early years initial teacher training (ITT): A guide for providers. Available at: https://www.gov.uk/guidance/early-years-initial-teacher-training-a-guide-forproviders

Recchia, S., \& Shin, M. (2010). "Baby teachers”: How pre-service early childhood students transform their conceptions of teaching and learning through an infant practicum. Early Years: An International Journal of Research and Development, 30(2), 135-145.

Redder, B. \& White, J. (2017). Implicating teachers in infant-peer relationships: Teacher answerability through alteric acts. Contemporary Issues in Early Childhood Education

Trevarthen, C. (2004). "Making Friends with Infants.” Paper presented at Pen Green Conference, Corby, England. July 3

Van Laere, Peeters, \& Vandenbroeck (2012). The education and Care Divide: the role of the early childhood workforce in 15 European countries. European Journal of Education, Vol. 47 (4).

White, E.J. (2016). Introducing dialogic pedagogy: Provocations for the early years, London: Routledge 
Table 1:1 Interviewee profiles of 8 participants who were working in a practice role with children aged from birth to three years at time of interviews

\begin{tabular}{|c|c|c|c|c|c|c|c|c|}
\hline Pseudonym & Jane & Karen & Valerie & Kim & Tanya & Donald & Matthew & Cara \\
\hline $\begin{array}{l}\text { Length of Service in Early } \\
\text { Years Practice }\end{array}$ & 10 years or more & $\begin{array}{l}10 \text { years or } \\
\text { more }\end{array}$ & $\begin{array}{l}10 \text { years or } \\
\text { more }\end{array}$ & $1-3$ years & $\begin{array}{l}10 \text { years or } \\
\text { more }\end{array}$ & $\begin{array}{l}10 \text { years or } \\
\text { more }\end{array}$ & 10 years or more & $4-6$ years \\
\hline Current Early Years Role & $\begin{array}{l}\text { Nursery School } \\
\text { Headteacher }\end{array}$ & $\begin{array}{l}\text { Early years } \\
\text { Teacher/ } \\
\text { Manager }\end{array}$ & $\begin{array}{l}\text { Deputy } \\
\text { Manager }\end{array}$ & $\begin{array}{l}\text { Early years } \\
\text { Practitioner }\end{array}$ & $\begin{array}{l}\text { Early Years } \\
\text { Teacher }\end{array}$ & $\begin{array}{l}\text { Owner / } \\
\text { Employer / } \\
\text { Director }\end{array}$ & $\begin{array}{l}\text { Early Years } \\
\text { Teacher/Manager }\end{array}$ & Childminder \\
\hline Early Years Provider Type & $\begin{array}{l}\text { Maintained } \\
\text { Nursery School }\end{array}$ & Pre-School & $\begin{array}{l}\text { Private Day } \\
\text { Nursery }\end{array}$ & $\begin{array}{l}\text { Private Day } \\
\text { nursery }\end{array}$ & Pre-School & $\begin{array}{l}\text { Private Day } \\
\text { Nursery }\end{array}$ & $\begin{array}{l}\text { Private Day } \\
\text { Nursery }\end{array}$ & Childminder \\
\hline $\begin{array}{l}\text { Age Group(s) of Children in } \\
\text { Current Role }\end{array}$ & 2 to 3 yrs & 2 to 3 yrs & $\begin{array}{l}\text { under } 12 \mathrm{~m} \text { to } \\
3 \mathrm{yrs}\end{array}$ & $12 \mathrm{~m}$ to $3 \mathrm{yrs}$ & 2 to 3 yrs & $\begin{array}{l}\text { under } 12 \mathrm{~m} \text { to } \\
3 \mathrm{yrs}\end{array}$ & $\begin{array}{l}\text { under } 12 \mathrm{~m} \text { to } 3 \\
\text { yrs }\end{array}$ & under $12 \mathrm{~m}$ to $3 \mathrm{yrs}$ \\
\hline $\begin{array}{l}\text { Highest Level of Early Years } \\
\text { Qualification }\end{array}$ & $\begin{array}{l}\text { Level } 5 \text { \& above } \\
\text { MSc } \\
\text { Educational } \\
\text { Leadership }\end{array}$ & 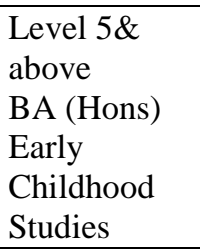 & $\begin{array}{l}\text { Level } 5 \& \\
\text { above } \\
\text { About to } \\
\text { finish BA }\end{array}$ & $\begin{array}{l}\text { Level } 3 \\
\text { Children \& Young } \\
\text { People's } \\
\text { Workforce } \\
\text { Diploma }\end{array}$ & $\begin{array}{l}\text { Level } 5 \text { \& above } \\
\text { Foundation } \\
\text { Degree in Early } \\
\text { Years Education } \\
\text { \& Playwork }\end{array}$ & $\begin{array}{l}\text { Level 5\& } \\
\text { above } \\
\text { Unspecified }\end{array}$ & $\begin{array}{l}\text { Level } 5 \text { \& above } \\
\text { Unspecified }\end{array}$ & $\begin{array}{l}\text { Level } 5 \text { \& above } \\
\text { BA(Hons) degree }\end{array}$ \\
\hline $\begin{array}{l}\text { Qualified Teacher Status } \\
\text { (QTS) or Early Years } \\
\text { Professional Status (EYPS) }\end{array}$ & QTS & EYPS & EYPS & No & No & EYPS & EYPS & EYPS \& EYTS \\
\hline Age of Participant & $40-44$ & $45-49$ & $30-34$ & $50-54$ & $40-44$ & $55-59$ & $30-34$ & $25-29$ \\
\hline Sex of Participant & Female & Female & Female & Female & Female & Male & Male & Female \\
\hline
\end{tabular}

Key: EY Provider Type ${ }^{1}$

Qualification Level ${ }^{2}$

QTS/ EYPS/EYTS ${ }^{3}$

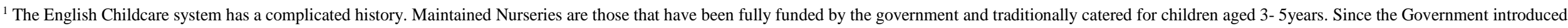

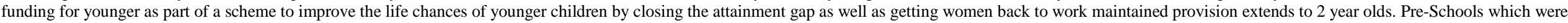

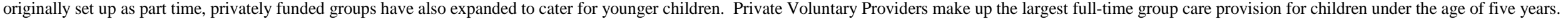

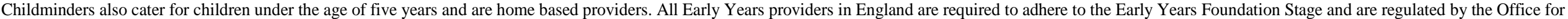
Standards in Regulation (Ofsted).

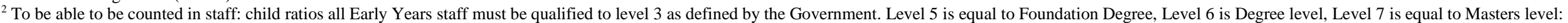
https://www.gov.uk/guidance/early-years-qualifications-finder

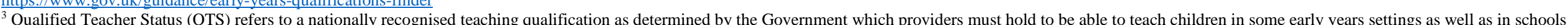

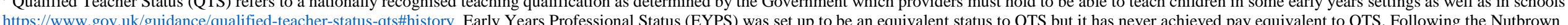
(2012) qualifications review EYPS was replaced by Early Years Initial Teacher Training with Early Years Teacher Status: https://www.gov.uk/guidance/early-years-initial-teacher-training-a-guide-for-providers
} 